Geopolítica(s) Revista de estudios sobre espacio y poder ISSN: 2172-3958

https://dx.doi.org/10.5209/geop.66403

\title{
The Power Struggle along the US-Mexico Border: A Space of Dehumanization and of Assertion of Justice
}

\author{
Mónica Socorro Romero Meza ${ }^{1}$
}

Recibido: 18 de septiembre de 2018 / Aceptado: 1 de junio de 2019

\begin{abstract}
The article explores the power relations between the US immigration policy and the practices of faith-based organizations at the US-Mexico border through qualitative methods. It studies how high-level technologies implemented at the border reduce migrants to mere targets, stripping them out from their human value. It also analyzes the experiences of three faith-based organizations located at Tijuana and San Diego to understand how their humanitarian work changes the normal perception of the border as a space that only serves the purpose of the State. I argue that despite of the violence lived almost every day at the border-heightened by the implementation of military techniques- undocumented migrants can momentarily find moments of peace and justice.
\end{abstract}

Keywords: dehumanization; faith-based organizations; militarization; technology; US-Mexico border.

\section{[es] La lucha de poder a lo largo de la frontera México-Estados Unidos: un espacio de deshumanización y de reivindicación de justicia}

Resumen. Este artículo explora las relaciones de poder entre la política migratoria de los Estados Unidos y las prácticas humanitarias de organizaciones religiosas en la frontera México-Estados Unidos, a través de una metodología cualitativa. En su análisis, considera cómo las tecnologías de alto nivel, implementadas en la frontera para controlar los cruces irregulares, reducen a los migrantes a meros objetos que tienen que ser manejados, despojándolos de su valor humano. Este artículo también analiza las experiencias de tres organizaciones religiosas ubicadas en Tijuana y San Diego para comprender cómo su trabajo modifica la percepción común de la frontera como un espacio que solo sirve al propósito del Estado. La autora argumenta que a pesar de la violencia que se vive casi diariamente en la frontera, intensificada por la implementación de técnicas militares, los migrantes indocumentados pueden encontrar momentos de paz y justicia.

Palabras clave: deshumanización; organizaciones religiosas; militarización; tecnologías; frontera México-Estados Unidos.

\section{[pt] A luta pelo poder na fronteira México-Estados Unidos: um espaço de desumanização e de demanda por justiça}

Resumo. Este artigo explora as relações de poder entre a política de imigração dos Estados Unidos e as práticas humanitárias de organizações religiosas na fronteira México-Estados Unidos, por meio de

$1 \quad$ Ph.D. Candidate in Human Geography; Wilfrid Laurier University (Canadá).

E-mail: rome5530@mylaurier.ca 
uma metodologia qualitativa. Em sua análise, ele considera como as tecnologias de alto nível, implementadas na fronteira para controlar cruzamentos irregulares, reduzem os migrantes a meros objetos que precisam ser manuseados, tirando-os de seu valor humano. Este artigo também analisa as experiências de três organizações religiosas localizadas em Tijuana e San Diego para entender como seu trabalho modifica a percepção comum da fronteira como um espaço que serve apenas ao propósito do Estado. A autora argumenta que, apesar da violência que ocorre quase diariamente na fronteira, intensificada pela implementação de técnicas militares, os migrantes sem documentos podem encontrar momentos de paz e justiça.

Palavras-chave: desumanização; organizações religiosas; militarização; tecnologias; fronteira México-Estados Unidos.

Sumario. Introduction. 1. Migration and border security in Political Geography. 2. Methodology. 3. Contextualizing the US-Mexico border. 3.1. The US-Mexico border: a history of militarization. 3.2. CBP technology and infrastructure in ports of entry and border crossings. 4. Discourses of US border security strategies: An analysis of US Customs and Border Protection Reports. 5. Faith-based organizations along the border: A humanitarian perspective. 5.1. The humanitarian side of the border. 5.2. Militarization and abuses on the US-Mexico border. 5.3. The expansion of military infrastructure beyond the US-Mexico border. 5.4. Humanitarian local organizations as creators of new opportunities for migrants. Conclusion. References.

Cómo citar: Romero Meza, Mónica Socorro (2019) "The Power Struggle along the US-Mexico Border: A Space of Dehumanization and of Assertion of Justice". Geopolitica(s). Revista de estudios sobre espacio y poder, vol. 10, núm. 2, 185-206.

\section{Introduction}

The US-Mexico border is 2,000 miles long and has 10 Border States, which represent a combined population of more than 10 million people (USEPA, 2016). Although divided by an international border, the region has strong links connecting migration, tourism, environmental issues, economic ties, and family and cultural relationships (Villareal, 2019). Despite its potential to become an area for real cooperation between both nations, it is a place more often characterized as a source of insecurity, threats and vulnerabilities. Most recently, it has become a site of militarization in which the concentration of border agents and military technology has covered the physical territory. This practice not only shapes the visual landscape, the local economy and the social norms, but also opens a moral question on how migrants are being exposed to harsh conditions and treatment, leading to them being the subjects of abuses, human rights violations, and even death.

The implementation of different types of security techniques, such as surveillance towers, fences, and border patrol agents along the border appeared in response to the increasing anxiety and xenophobic discourses against immigrants. These strategies led to profound changes on how undocumented immigration was portrayed in political discourses since it turned into an issue of national security. This response created a linkage between undocumented immigrants and the War on Terror, increasing the negative portrayal of the "illegal" immigrant (Pope \& Garret, 2013). After $9 / 11$ and the change in security narratives, states enhanced the political principle of protectors of citizens (Walters, 2004). This caused the development of measures intended to govern mobilities (Amoore, 2006; Bigo, 2007; Mountz, 2011) and to assert the state's sovereign power (Bosworth, 2008; Brown, 2017). 
Despite the fact that diverse articles have demonstrated the seriousness of US responses against unauthorized migration, the use of technology as a mechanism itself, which serves to dehumanize immigrants, has not been given the same attention in scholarly analysis. Since high-tech methods are often unsightly, people tend to believe that they are less important and less intrusive. The deployment of drones and other surveillance techniques has had little or no public opposition from immigrant rights organizations, NGOs and environmental groups (Barry, 2010). However, these same mechanisms have established a new dynamic in the area, one in which the human factor has been reduced in the entire border experience.

This article aims to explore the relations of power between the Customs and Border Patrol (CBP) and the humanitarian practices of three faith-based organizations operating at the Tijuana-San Diego border crossing. It aims to provide a different perspective in which the border is not merely seen as a contentious space which works for the service of the state but also as one that can offer humanitarian grounds to civil society groups that offer moments of peace and justice to those trying to cross. This paper is divided in three main sections. After a short discussion of how migration and border security are portrayed in the discipline of political geography and the methods segment, the first main section will focus on contextualizing the US-Mexico border, explaining its militarization process and the Customs and Border Patrol (CBP) technology implementation in the area. The second section will analyze the policy discourses of the CBP showing how these constantly dehumanize migrants and prioritize the use of high-level technologies. The third and final section explores the role of faith-based organizations at aiding migrants. It also discusses how their actions give a humanitarian meaning to the border, countering state discourses.

\section{Migration and border security in Political Geography}

The recent decades of scholarly research in political geography have increasingly focused on migration and border security. The literature is relevant as it offers a new perspective to study how spaces become political and how power relations become visible when crossing strict mobility controls (Amilhat \& Giraut, 2015; Hayes \& Mason, 2013). Empirical research in political geography has shown how borders are proliferating and they are now encountered not only at the edge of the state but also in different virtual and physical spaces (Amoore, 2006; Walters, 2006; Paasi, 2009). Various types of migration flows have been affected as border security had considerably increased shaping deeper complexities in political and social life (Johnson et al., 2011; Jones, 2016).

Debates in the literature of border studies intensified after the $90 \mathrm{~s}$ as globalization changed the role of borders and the patterns of migration in the international arena. These patterns involved different groups of people seeking security, political liberties, human rights, and new education and job opportunities. These migratory changes are usually paired with political, social and economic developments around the world. For example, Sassen's (2014) term of "expulsions" is an example of how the current capitalist order enables the expulsion of numerous people from the economic and social systems through a variety of complex instruments from political policies to financial instruments. This in turn produce "elementary 
brutalities", including the displacement of large populations to refugee camps. The nation-states' systematic responses towards these new mobilities include the multiplication of boundaries and protectionist narratives (Amilhat \& Giraut, 2015). These narratives are also part of a major categorization between those who have the right to enter sovereign countries versus those who are seen as "unwelcoming migrants". Thus, free movement has become a privilege for those who are deemed worthy and useful (Pries \& Pauls, 2013).

The changes in the international immigration system and the refugee protection framework around the world led to the acceptance of new strategies as elements to control the movement of people (Crepeau et al., 2007). Mainly after the 9/11, almost any action became justifiable. Security concerns were prioritized in Western states and among these discourses, immigration became the centerpiece of these debates. The US, in particular, has shown a wide variety of strategies to securitize their borders. For example, the presidential election of 2016 demonstrated that the idea of a border wall between Mexico-US is still a popular one to deter immigrants and to show state's capabilities to maintain their territory safe, despite its violent role in controlling migrants in pervasive manners.

\section{Methodology}

Social reality and our understanding of it are messy (Salter, 2013). Thus, a single technique might not be sufficient to study diverse social practices, including the geopolitics of migration. This paper is based on multiple qualitative methods, particularly, policy research, discourse analysis and semi-instructed interviews. This study examines the US strategies of border security, based on high-level technology, as contributors of violence, discrimination and the dehumanization of people crossing the border. The methodology consists of three sections. In the first phase, the author uses policy research and discourse analysis to analyze the US Borders and Customs Protection (CBP) narratives. The discourse analysis methodology allows the understanding of language used within a particular context, considering that no language is totally devoid of meaning (Alvesson \& Karreman, 2000).

The analysis focuses on showing the importance given to the implementation of high-level technology in three of the most relevant documents of the CBP. It also considers the anti-immigrant discourses that have surrounded their establishment. Through a critical examination of official reports, I aim to show that the US government has been framing the implementation of military elements as a defensive action aimed to protect US citizens against the "immigrant threat". Thus, the discourse analysis will shed light into narratives that marginalize and enable the exclusion of others through the effects of power relations (Cheek, 2004).

In the second phase, the author conducted semi-structured interviews to understand the experience and opinions of three faith-based organizations which work closely with undocumented migrants. Even though the aim of all interviews is to use questions to understand, thoughts, feelings, beliefs and behavior of people (Stuckey, 2013), interviews styles range widely depending on the type of research design. In this case, I conducted semi-structured interviews as they allow the researcher to have direction in the conversation, but also flexibility to identify new topics and concerns that the interviewees might express (Wilson, 2012). The ques- 
tions elicit information on how the directors of these organizations perceive the US enforcement initiatives and how these affect immigrants crossing the US-Mexico border. These interviews provide an alternative perspective to that of the US government immigration policies, by representing the humanitarian vision and concerns of the immigrant community and civil-society organizations.

The last phase of the field research consisted in data analysis, which included triangulation to incorporate data from the interviews, policy review and discourse analysis. Triangulation is a useful method in qualitative research as it allows the researcher to develop a comprehensive understanding of a phenomenon using more than one method or data sources (Carter et al., 2014).

The field research was completed in one of the most dynamic crossings of the US-Mexico border: the Tijuana-San Diego corridor. Although the corridor El PasoCiudad Juarez was the first one where the Border Patrol implemented a high-level border control operation ("Hold the Line" in 1993), it was rapidly replicated in the Tijuana-San Diego border crossing with the "Operation Gatekeeper", as this corridor accounted for more than 40\% of irregular entries in the early 1990's (USCBP, 2019a). The Tijuana-San Diego corridor was chosen for this study for three main reasons: 1) it was one of the first corridors where border enforcement was heavily implemented due to its relevance as the preferred corridor of irregular migrants crossing to the US; 2) the "Operation Gatekeeper" was recognized as a "success story" according to the US government which led to the implementation of similar operations in Arizona and Texas, and 3) it was the geographical epicenter of antiimmigrant narratives and security concerns from the US politicians in the $90 \mathrm{~s}$, which consequences are still experienced nowadays through militarization practices.

\section{Contextualizing the US-Mexico border}

\subsection{The US-Mexico border: a history of militarization}

The US-Mexico border has a long history of cross-border population movements. After the annexation of territories such as California, New Mexico, Texas and Arizona to US territory in the 19th century, a constant interaction and flow of people took place between both nations. The region became a unique and dynamic space where two different cultures blended (Anderson, 2003; Orraca, 2013).

The militarization of the US-Mexico border began in the 1980's, after undocumented crossings increased considerably when the US restricted the labor movement by ending previous legal working permits (Klein, 2013). In the next decade, immigration in general emerged as a national priority to the US when terrorist acts took place along their territory (Waller, 2005). Different operations, such as Hold the Line (1993) in El Paso, Texas; Gatekeeper (1994) in San Diego, California; and Rio Grande (1997) in Brownsville, Texas were implemented in the US-Mexico border to prevent smuggling of drugs and illegal crossings. These programs achieved mixed results, since they were successful on impeding migrants to cross through known locations, but they forced migrants to look for more dangerous routes. Border walls, surveillance systems and increase of border patrol agents have been resources used by the US to try to mitigate the irregular crossings at 
their southern border (McCune \& Soden, 2009). In addition, high level technologies are used as part of a militarization process which aims to deter migrants.

With respect to the effectiveness of the militarization, scholarly research has demonstrated that these methods had opposite results from what was expected (Massey \& Sánchez, 2010; Angelucci, 2012). After their implementation there were fewer undocumented migrants trying to cross, but those who achieved crossing stayed longer to recoup the higher entry cost (Angelucci, 2012). Due to this shift in security discourses and the use of more elaborated technologies to control human movement, undocumented migration has become a representation of a moral dilemma. The dehumanization of migrants and the violation of their human rights are interrelated to the militarization of the border (Ahn et al., 2013).

The intensified border enforcement has contributed considerably to dehumanize migrants by allowing their deaths without any sanction (Doty, 2011). More recently, President Trump's actions in immigration policy have shown how bordering practices are even more dispersed across the US territory, social practices, and political discourses, which are mainly intended to divide and differentiate. However, his discourse during and after his campaign often revolved around the geographical space of the border and its initiatives of adding or expanding hard border controls. By using the border as a militarized instrument, migrants safety will be compromised.

The militarization process began almost forty years ago, the US-Mexico border and its dynamics have changed considerably. Since its formal establishment, the border was never homogenous; different border states, and thus every port of entry, had diverse dynamics subject to different political, social, and discursive interactions. Although the border has been constantly evolving beyond the idea of acting as a mere territorial line dividing two countries; recent discourses prove that the states' political idea of keeping "undesirable" immigrants out has not yet changed substantially during the last years. The division of who is worthy to enter US territory becomes more visible due to the implementation of stricter (hard and soft) border controls.

\subsection{CBP technology and infrastructure in ports of entry and border crossings}

During the 1990s, under several operations, the Border Patrol (BP) increased their activities by shifting their operations from the traditional enforcement strategy to a more modern multiagency organization that relied on up-to-date mechanisms. The focus also changed: rather than apprehending unauthorized migrants after entry into worksites, they were preventing their entrance or intercepting them at the border. The new strategy was based on "prevention through deterrence", in which the $\mathrm{BP}$ aimed to concentrate most of the resources on major entry corridors to establish control (Argueta, 2016).

Since the round of immigration reform proposals in the mid-2000's, border security has significantly increased in all sectors (Graham, 2013). Figure 1 depicts the steady growth of the Border Patrol enacted budget from 1995 to 2017, which reflects the level of appropriations, including personnel, infrastructure and surveillance technology. 
Figure 1. Enacted Border Patrol Program budget from 1995 to 2017 (dollars in thousands)

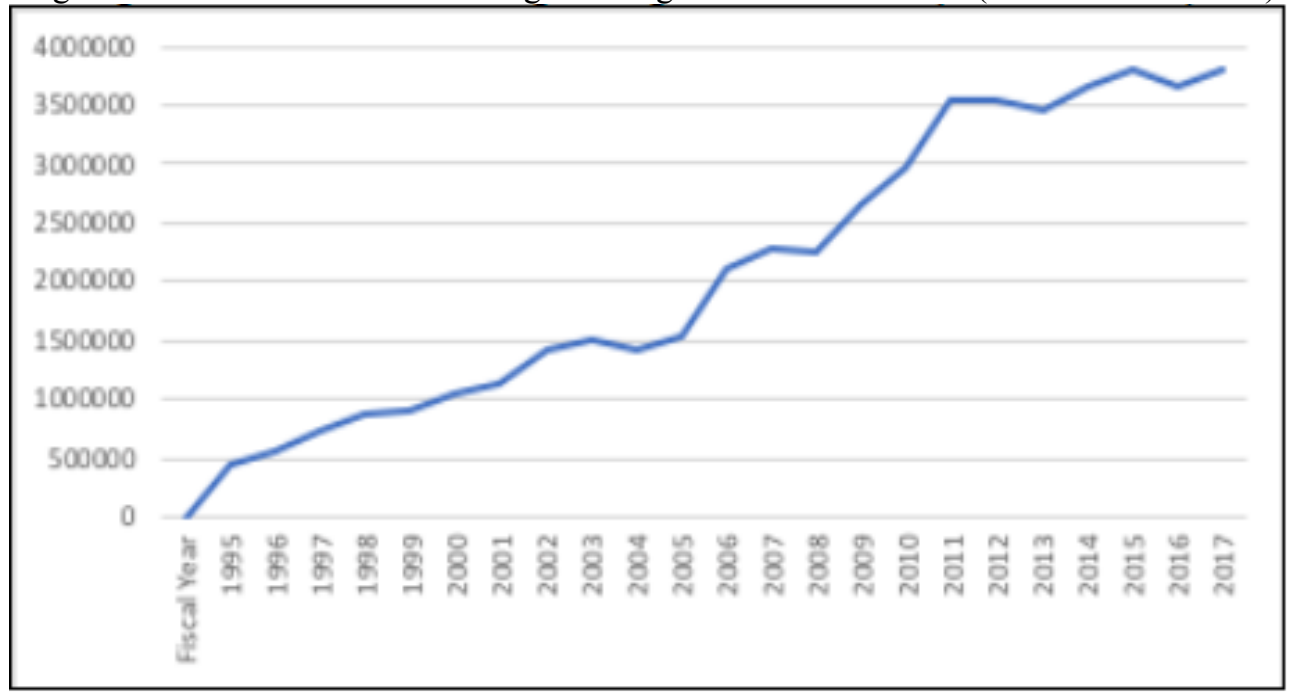

Source: US Customs and Border Protection (2017), Stats and Summaries, Border Patrol Fiscal Year Budget Statistics (FY1990-FY2017).

On the other hand, up to 2016 the US Customs and Border Protection (CBP) department is considered one of the world's largest law enforcement organizations with more than 60,000 employees (USCBP, 2019b). Figure 2 shows the increase of agents deployed on the two most important border sectors by fiscal year from 1998 to 2017. It is observed that the largest number of border patrol agents has been placed at the southwest sector of the border.

Figure 2. Border Patrol Staffing by Fiscal Year

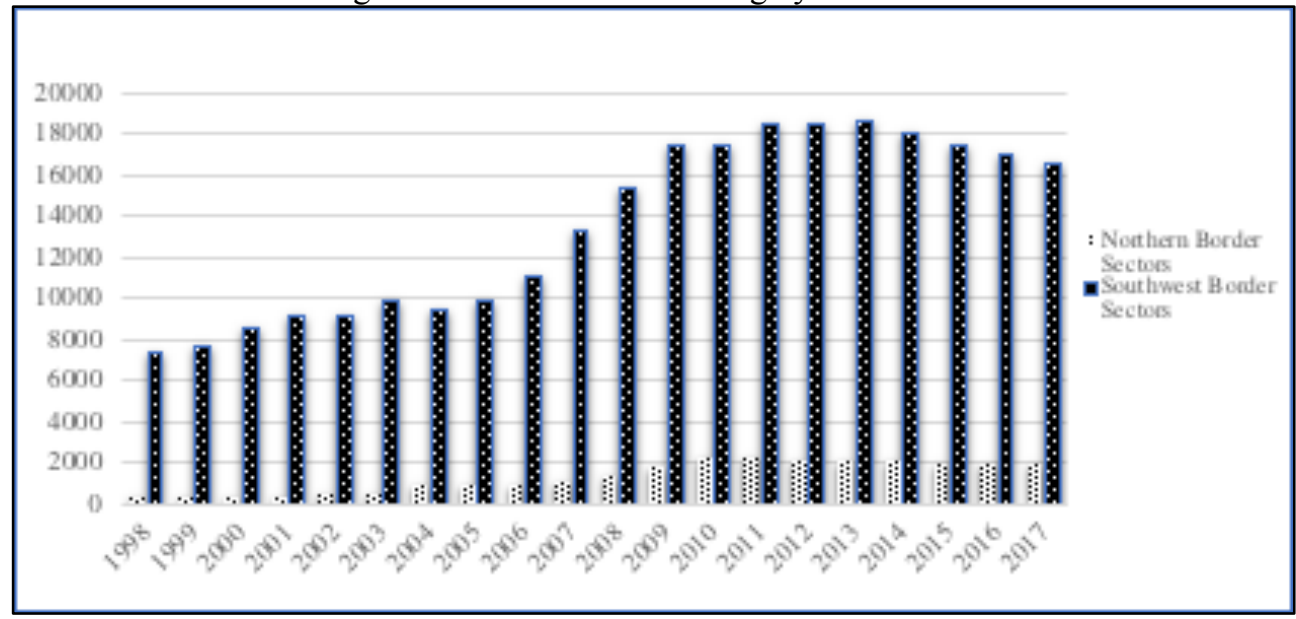

Source: US Customs and Border Protection (2017), Stats and Summaries, Border Patrol Fiscal Year Budget Statistics (FY1990-FY2017).

The CBP's facilities and infrastructure encompass several sophisticated targeting and communication systems, which include: 
- Border Tactical Infrastructure: includes roads, lighting, pedestrian fencing and vehicle barriers, and other mechanisms such as mobile night vision scopes, directional listening devices, etc. As of October 2014, the DHS had installed 352.7 miles of primary pedestrian fencing, 299 miles of vehicle fencing, and 36.3 miles of secondary fencing.

- Network of remote video surveillance systems (RVS): Including day and night cameras that are used to detect incursions and are controlled by border patrol stations.

- Sensor devices: Including thermal imaging devices and seismic and magnetic sensors, which are linked to a computer network called the Integrated Computer Assisted Detection database (ICAD). ${ }^{2}$

- Unmanned aerial systems: Equipped with Vehicle and Dismount Exploitation Radar (VADER), which serves to detect, identify, classify and track movements over land. They are deployed in areas considered too risky for field personnel or manned aircrafts (Department of Homeland Security, n.d.).

This list highlights the increasing reliance on innovation and technology to control borders. The adoption of a broad set of new technologies has transformed the US border security strategy into a less human process. This strategy consists of deploying fewer agents in specific areas while maintaining the ability to counter unauthorized crossings. Thus, by establishing this type of technology, the Border Patrol has transferred the responsibility of the consequences, in the form of migrants' apprehensions, deportations and deaths, to a new set of mechanisms, deflecting official charges or blame.

The main purpose of these elements is to deter migrants from crossing in particular areas of the border, particularly where city entries are established. Thus, this enables the creation of new migrant crossings through mountain ranges or desert lands. This process turns the geographical space to a strategy to control unauthorized migration, since the CBP can locate responsibility outside its jurisdiction by letting nature "take its course" (Doty, 2006).

\section{Discourses of US border security strategies: An analysis of US Customs and Border Protection Reports}

Much of the official data about border security and enforcement outcomes is obtained through the CBP reports and official documents. For this research the author analyzed those documents that portray the goals and main pillars of the agency since they provide a broader perspective on how the Border Patrol manages their resources to protect the border. The documents selected were: Vision and Strategy 2020, Border Patrol Strategic Plan 2012-2016, as it was the latest plan published by the CBP, and the National Border Patrol Strategy 2004. Through the critical reading of these governmental reports, this analysis shows that the US government

2 The Border Patrol staff constantly monitor the ICAD system in order to re-position RVS cameras towards different locations when sensor alarms are activated. Later on, field agents are usually alerted and coordinate the response. 
has prioritized the use of military technologies on the border. Furthermore, it also aims to demonstrate the effects of this type of discourses as it serves to dehumanize migrants by referring to them as targets.

Vision and Strategy 2020 describes strategic goals in which the Border Patrol commits to identify and eliminate cross-border criminal and illegal activity. In this section, it is explained that all of the efforts are focused on detecting possible threats in cross-border activities. In their narratives, diverse elements are considered high-risk that put American interests at danger, including terrorism, narcotics smuggling, human trafficking, as well as the undocumented movement of people. All of these activities are considered illegal threats that have to be countered by the largest law enforcement organization in the US. It is noticeable that the category of what is illegal has stretched to include threats ranging from weapons of mass destruction to vulnerable people seeking better life opportunities. By framing the unauthorized movement of people as an activity standing outside the state's legal system, migrants' existence becomes a synonym of illegality, which in turn becomes a threat to US governance.

Despite many debates on this topic, the phrase "illegal alien" is still used to describe subjects crossing the border, in different US reports and official websites. For example, in the Border Patrol Overview section of their website, it is explained that since 1994, "[the Border Patrol mission] remains unchanged: to detect and prevent the illegal entry of aliens into the United States" (USCBP, 2018). Both categorizations - illegal and alien - act as elements of criminalization and discrimination, reinforcing the idea of otherness and transforming these subjects into socially undesirable persons who can be abused or killed.

The Vision Strategy 2020 mentions the CBP goal to "Promote Organizational Integration, Innovation, and Agility" (USCBP, 2015: 36). It refers to the responsibility of the agency to operate efficiently by optimizing processes and to support operational needs to ensure all of the missions' success. They describe the agency's commitment to optimize their operations through agility and innovation by taking advantage of technological advances and innovative practices. They consider the implementation of technology to be a way to reduce costs and improve operational effectiveness, however this purpose has been stretched to even use high-end military technologies in a non-war zone.

On the other hand, the Border Patrol Strategic Plan 2012-2016 describes in a more specific way how the BP uses high-tech elements to improve its job in protecting the US borders. The 2012-2016 BP plan is characterized by being a riskbased strategy rather than a resource-based strategy, as it was in 2004. Currently, the agency uses a risk-based approach to counter what they consider to be the highest threats through the "Information, Integration and Rapid Response program." Information includes the use of technology and intelligence to face threats along the border, providing the basis for the Integration phase (fostering partnerships with other federal agencies) and the Rapid Response phase (responding quickly to changing threats).

According to the Border Patrol Strategy, employing technology has been a relevant factor to manage risks along the border; they claim that without technological elements "the Border Patrol cannot operate in an effective, efficient, and risk-based manner" (USCBP, 2012: 15). The report mentions that CBP works jointly with other federal organizations, such as the Office of Technology Innovation and Ac- 
quisition (OTIA), to ensure that their technological needs are addressed properly. However, the efficiency of high-end technologies, such as unmanned aerial systems, has been largely questioned due to the meager results it offers in comparison to the amount of money which has been invested in them (Ewing, 2010; OIG, 2014).

It is clear that since $9 / 11$ and the shift to a risk-based strategy, deploying the newest technology has been the priority of the BP. By doing this, they are increasing the dangers that migrants have to face, but most importantly, they do not address in these documents the hazards that they are exposing migrants to. The US government is not only preventing them from crossing, but they are causing particular conditions that increases migrants' vulnerabilities. All these reports show the importance that CBP gives to technological innovations; however, they do not explain how these technologies affect the human beings encountering them.

Another important element of the BP strategy is their "Change Detection Capability", which is aimed to measure the changing level of threats in low-risk areas by gathering information. This strategy enables the BP to focus on the highest- risk areas, but to keep monitoring low-risk sites to determine if new threats become relevant. These new strategies played a key role in transforming the monitoring of migrants into a more mechanized system with less human intervention as surveillance cameras and drones in some specific areas have replaced BP agents.

This new approach has three main consequences: giving more appearance of control on the border, fulfilling their objective of "preventing through deterrence", and avoiding their own responsibility for the deaths of migrants who try to cross the border. By covering the major areas (with Border Patrol Agents) and certain low-risk sites (with drones), the government's reasoning relies on letting migrants look for more dangerous paths in order to increase their possibilities of injuries or death. The deterrence strategy became more than a symbolic intention when migrant bodies started to be found further away from populated areas, presumably killed due to the nature conditions.

In comparison to the other reports, the National Border Patrol Strategy 2004, shows how military technologies are used in tactical infrastructure. For example, it mentions that "in 2004 the Border Patrol became the very first civilian law enforcement agency in the world to use UAVs to carry out a civilian law enforcement mission" (USCBP, 2004: 2).

This document explains the importance of maintaining a strong enforcement posture along the southwest border, even though it acknowledges the deaths of thousands of migrants trying to cross. The document mentions "hundreds of aliens die each year as a result of failed smuggling efforts while attempting to cross the Southern border" (USCBP, 2004: 5). Importantly, the report does not make the distinction between those who cross as drug traffickers and those who are crossing to pursue better opportunities of life. Moreover, "national security" is mentioned in different sections of the report as the ultimate goal of the Border Patrol. However, national security is not a task that the border security system is designed to accomplish, since the military was created specifically for that purpose.

Military technology has become part of the daily technical elements that the Border Patrol is using to control its frontier (Miller, 2013). Over the past years, under the "national security" discourse the DHS deployed unprecedented levels of resources, including personnel and technologies, to support the control of borders. 
From the National Border Patrol Strategy in 2004 to the Border Patrol Strategic Plan 2012-2016, there was a change in agency goals: it evolved from the establishment of a resource-based plan to a risk-based one. The 2004 strategy represented the acquisition and deployment of the personnel and infrastructure intended to maintain operational control in the area, and in 2012 these techniques became the foundation of an intelligence-driven agency capable to rapidly respond to the highest risks at the border (USCBP, 2012). Along the past years the CBP has been consistent with increasing the resources focusing at the southwest border, justifying their actions by criminalizing migrants.

\title{
5. Faith-based organizations along the border: A humanitarian perspective
}

\author{
"Before, there was no way to cross illegally, today there \\ is no way to cross legally" (Mr. Enrique Morones, \\ Founder of Border Angels).
}

Due to the increasing violations of human rights against immigrants, different organizations started to work with and advocate on behalf of immigrants from Mexico or transit migrants from Central America. Some of these institutions are local while others are part of transnational organizations; but all of them try to protect the right of immigrants exposed to difficult conditions along their journey.

Faith-based organizations have emerged as important and recognized actors, as they historically have offered humanitarian aid to vulnerable groups and acted as sites of sanctuary where refugees could seek shelter or protection. Religious groups have been the most vigorous in monitoring human rights abuses at the border and providing humanitarian services to immigrants. The current policies against migrants contrast with their ideology as these challenge their belief that migrants have to be treated with respect as every other human being. The links between theology and migrant well-being are usually based on the social doctrine of the Catholic Church, which usually challenge nation state enforcement practices (Hagan, 2008). Faith-based advocacy has grown substantially in recent years, as it became more influential and established powerful coalitions to provide migrants just treatment in all the stages of the migratory process. Although their role in aiding immigrants and refugees has always been prominent, there are a few studies analyzing the importance of religion and faith based-organizations from the decision to migrate through arrival.

The faith-based organizations have played a relevant role in the migratory process in Mexico, since religion is a construction embedded in the every-day practices of migrants. Religion is a locality since it lives through specific people; migrants cannot leave their faith in their home country, it crosses borders with them. Migrants journeying to United States usually feel vulnerable; thus, faith-based organizations become a familiar site in which they are not judged or discriminated against. They are offered assistance and religion represents a linkage to what they believe and feel in a personal manner.

Church-based organizations provide a more complete approach to meeting individuals needs by not only offering refuge but also providing caring staff and supportive networks. Many migrants have turned to churches, shelters and civil organ- 
izations as they lack personal networks or resources to assist them. However, their activities and practices have broadened considerably in the interests of migrants; for example, they have become a meeting point where migrants can gather, talk about their experiences and exchange ideas with one another. These help migrants to cope with feelings of isolation and loneliness (Hagan, 2008).

They have also come to constitute a political actor who performs a strong advocacy for human rights, involving their multiple levels of church hierarchy. They clearly represent a contestation to the state, since they enable the pursuit of social justice for migrants by organizing public and energetic protests, in which they try to make visible - locally and internationally - migrants' conditions. Moreover, protests or activities organized by faith-based institutions usually carry more symbolic elements than secular protests. Most of these organizations, working along the US-Mexico border, use Mexican or Latino traditions, which allows ethnic resilience to counter American culture. Most of these activities occur in symbolic places, such as the border, the site which conveys rejection and death, but which also represents an opportunity to create spaces of peace and hospitality (HondagneuSotelo et al., 2004). This clearly contributes to express a political statement that kindness transcends the reality of border enforcement and violence.

Apart from official Border Patrol data on border enforcement, the second major source of information in this research is the data based on the three interviews conducted to the directors of relevant civil organizations that help immigrants. Border Angels, American Friends Service Committee (AFSC) and Casa del Migrante have in common the objective of aiding Mexican and Central American migrants to achieve a better treatment, as well as advocating for a just immigration reform.

The analysis of the interviews will be divided into four different sections: a) faith-based institutions: a humanitarian perspective; b) militarization and abuses on the US-Mexico border; c) the expansion of the military infrastructure beyond the US-Mexico border, and d) humanitarian local organizations as creators of new opportunities for migrants.

\subsection{The humanitarian side of the border}

To begin with the analysis, it is relevant to mention that these organizations are faith-based and they have, mainly, a humanitarian understanding of the problem. Their concerns differ from those that the US government has, since they consider immigrants to be human beings, which have to be treated with respect and compassion. For example, the Border Angel actions are guided by the following Biblical verse: "When I was hungry, who gave me to eat? When I was thirsty, who gave me to drink?" (Matthew, 25:35). To serve migrants no particular religious beliefs are required, their mission entails a moral responsibility to those who are in need.

They freely offer their services without expecting any reciprocation on the part of the receiver. Their practices enact an ethical responsibility that is prior to any questioning and that transcends particularities of individuals such as nationality, legal status, age and sex. Thus, their actions are based on recognizing the universal conditions that every human being has, like hunger or thirst. For many reasons, this approach contrasts the one made by the US government. For example, US border law enforcement is actively and constantly making differences by race or legal status, resulting in criminalizing innocent people and putting their very existence at 
risk. On the other hand, the organizations' practices exceed such reductions by considering migrants to be actual human beings with needs.

The importance of these organizations does not only stem from the humanitarian aid that they offer to migrants, but also from their labor of opening new paths to achieve a just treatment for these persons. The USA, as a nation state, has always reaffirmed its borders and protected its national identity. Even though these humanitarian organizations are not advocating the elimination of the border, they are changing the conditions of this territorial space with their humanitarian interventions. They are establishing points of peace and humanity, which give certain hope to immigrants trying to get better opportunities for themselves and their families.

In the interview with Mr. Morones, Founder of Border Angels, he explained how his organization offers opportunities that favor immigrants but also that challenge the state authoritarianism with regard to its border strategy. He explains that they constantly carry out activities in the Friendship Park (located on the USMexico border), which is considered a bi-national reunion site between immigrants and their friends and family at the Mexican side of the border. In 2014 for Children's Day, Border Angels managed to convince the "migra" (US Immigration police) to open the emergency door for a few minutes, allowing the MexicanAmerican children to meet their parents who had been deported to Mexico. In 2015 they managed to obtain more benefits, since "the door was open for 15 minutes and four different families had the opportunity to gather and hug each other". ${ }^{3}$ This type of practice engages a double-reading of the border: on one side, they are responding to a situation that requires immediate attention (separation of families through deportation), fulfilling their moral responsibility as human beings and/or Christians; and on the other side, they are also demystifying the border as a violent site operated exclusively by the CBP. The opening of the "Door of Hope" had been carried out annually until 2018. The US authorities decided to stop it after a drug smuggling conviction emerged from one of the persons who was a participant in the event. During the opening of the door in 2018, the US citizen married to a Mexican woman in a surprise ceremony (Morrisey, 2018). Although the conviction was against the groom, a US citizen; Rodney Scott, chief of the San Diego Border Patrol Sector announced the ending of this event as the CBP has to uphold their responsibility of protect their borders between official ports of entry.

\subsection{Militarization and abuses on the US-Mexico border}

When asked about the militarization of the border, the three organizations agreed that abuses were considerably higher when these physical and technological elements were put into function. The consequence of having a "militarized psychology around is putting areas or zones of conflict where you are going to have people dying, without looking to the root causes of migration", 4 says Mr. Prado, who has been working for AFSC since 2003.

For Mr. Prado, criminalization has been the result of the militarization of the border, particularly after 9/11. According to him, after the New York terrorist at-

Interview to E. Morones (President's Border Angels, San Diego, California) on 7 August 2015 by M. Romero. Interview to B. Prado (President's American Friends Service Committee. San Diego, California) on 6 August 2015 by M. Romero. 
tacks, the US government used the national security discourse to justify the intensification of their border enforcement. Prado says: “They don't say to stop the flow of labor, but they say to identify criminals and terrorists. Their physical presence became a crime". 5

The Border Patrol and other US law enforcement considered immigrants to be less than human beings throughout the establishment of several legal provisions and the strict border policies. That also has increased the abuses against this vulnerable group of people. As Mr. Morones mentioned, "it is easier to commit abuse against somebody if you believe he has less value than you". ${ }^{6}$ According to him, the immigrants not only suffer abuses from the Border Patrol, but also have to face difficulties in their journey through Mexico, mainly from the different organized crime groups. Rev. Murphy, Director of the Casa del Migrante in Tijuana and former head of the Hispanic outreach for the Archidiose of Kansas City, talks about how migrants are abused in their journey through Mexico and how they are forced to commit criminal acts. "The polleros or smugglers «help» migrants to cross if they also take drug packages with them,", Rev. Murphy says.

According to Mr. Prado and Mr. Morones, racial profiling has been used as a law enforcement technique, which can be observed in the dramatic expansion on surveillance and information-sharing practices between the Department of Homeland Security and other federal agencies. This racial profiling can be observed not only in detention centers for immigrants, but also in common-life situations for people who do not fit the "American profile". According to Ramirez, Coordinator of the American Friends Service Committee's Project Voice and a MexicanAmerican citizen, "despite the fact everyone in my family had legal status in the United States, all of us were searched, handcuffed, detained or arrested at some point" (Ramirez, 2011: 36).

Mr. Morones asks:

Why the wall in the US-Mexico border and not with Canada? Of 27 cases of terrorists entering or intending to enter US territory since the First World War, not one has entered through its southern border; all of them have entered through their northern border or other ports of entry... [the militarization] has been based on racist practices. ${ }^{8}$

Aspects such as power control and apparent supremacy are noticeable along the border, where the agents use surveillance mechanisms for control, enabling the immigrant to become permanently visible.

\subsection{The expansion of military infrastructure beyond the US-Mexico border}

The militarization of the border has taken different forms, as Mr. Prado argues, it also has enabled the establishment of a lucrative industry complex in which the US government profit from it. "There is a whole industry around prison constructions

\footnotetext{
Interview to Prado, 2015.

Interview to Morones, 2015

Interview to P. Murphy (President's Casa del Migrante, Tijuana, Mexico) on 8 August 2015 by M. Romero.

Interview to Morones, 2015.
} 
and prison sentences for people who return... and also a military industrial complex, corporations that are contracted to build barriers, to create technology, infrastructure, even to create drones and helicopters to patrol the border," AFSC Program Director. The border military complex not only has made the targeting of human beings surgically precise, but also has created a whole lucrative sector in which many global and national private companies benefit from legislations escalating border militarization. Rev. Murphy also shares his vision:

I live in a fourth floor. I have a nice view but I can also see the powerful lights in the border all night; living here is like living between Israel and Palestine... companies that sell technology or weapons for war are present in the border. It is a huge business; [the US] is spending millions of dollars to maintain the security in the border. ${ }^{10}$

As an example, in 2014, the Israeli arms maker Elbit Systems Ltd won a US DHS contract to provide surveillance technology. Elbit Systems Ltd deployed military technology on the West Bank and Gaza in the last years; according to Corporate Watch, $85 \%$ of drones used by the Israeli military are manufactured by Elbit and "are used by Israel army in daily surveillance and attacks in Gaza" (Corporate Watch, 2015).

Another finding obtained from the interviews and related to the consequences of the US using military technology, as part of their border strategy is the extension of the same mechanisms to the Mexican southern border and even other segments of society. Mr. Prado mentions:

Mexico has had an observant role in allowing the militarization of the border. They see its role as an extension of US policy by militarizing its southern border; under the United States conditions, Mexico does the same with its border with Guatemala and Belize...you see different types of operations but with similar objectives...such as ceilings of guards, barriers to stop the flow of migration of Central America into Mexico, and, in fact, today there are more Central Americans being deported from Mexico than from the United States. ${ }^{11}$

As Mr. Prado mentions, the regional perspective is also relevant in analyzing the role of the US securitization beyond its borders. Nowadays, Central American migrants are not only facing the US securitization practices but the expansion towards the Mexico's southern border as well. Under the guidance and financial support of the US, Mexico announced in 2014 the implementation of its Southern Border Plan which included sending federal police to the border, opening more checkpoint and the implementation of surveillance technologies. During that year, Mexico deported 107,814 migrants, an increase of $13 \%$ from the previous year (Boggs, 2015). The following year became a turning point in the region as Mexico led the number of apprehensions of Central Americans instead of the traditional US

Interview to Prado, 2015.

Interview to Murphy, 2015.

Interview to Prado, 2015. 
Border Patrol. Thus, those who previously would have made it to the US border now were being apprehended by Mexican authorities.

The increased Mexican enforcement capacity reshaped regional dynamics and trends in apprehensions and deportations of Central Americans. Since the Southern Plan implementation, patrols, deportations, migration raids and government checkpoints along the routes increased dramatically, forcing migrants to find new modes of travel and make it difficult for them to reach shelter and humanitarian aid (Iacson et al., 2014; Brigden, 2018). Along these new dangerous routes, Central Americans also face other risks such as kidnappings and extortion of money from drug cartels and gangs. Despite of not having a physical wall, Mexico represents an enormous obstacle for those seeking better opportunities in life.

In more recent years, the Central American mobility dynamics in the region have also changed to avoid Mexican and US enforcement control. These strategies include, most prominently, asking for asylum in Mexico instead of the US, which puts pressure on the Mexican government to offer adequate services while this group of people wait for their refugee decisions. Another strategy is travelling in Caravans, which gives them major visibility and increased protection. These new patterns have changed the regional dynamics as Mexico is both containing and receiving immigrants arriving from the Northern Triangle. Although Mexico seems to have a more prominently key role nowadays, the US presence is increasingly stronger in the region through vast securitization practices and narratives, such as the threat to close the US-Mexico border and cutting off aid to Central America (Meissner \& Pierce, 2019).

Table 1. Merida Funding for Mexico by Aid Account (dollars in millions)

\begin{tabular}{|c|r|r|r|r|r|r|r|}
\hline Account & FY2010 & FY 2011 & FY 2012 & FY 2013 & FY 2014 & $\begin{array}{r}\text { FY 2015 } \\
\text { request }\end{array}$ & $\begin{array}{r}\text { FY 2016 } \\
\text { request }\end{array}$ \\
\hline ESF & 15.0 & 18.0 & 33.3 & 32.1 & 46.1 & 35.0 & 39.0 \\
\hline INCLE & 365.0 & 117.0 & 248.5 & 195.1 & 148.1 & 80.0 & 80.0 \\
\hline FMF & 5.3 & 8.0 & N/A* & N/A & N/A & N/A & N/A \\
\hline Total & 385.3 & 143.0 & 281.8 & 227.2 & 194.2 & 115.0 & 119.0 \\
\hline $\begin{array}{l}\text { Notes: ESF=Economic Support Fund, INCLE=International Narcotics Control and LaW } \\
\text { Enforcement, FMF=Foreign Military Financing. } \\
\text { *Since 2012, FMF assistance was not included as part of the Merida Initiative. }\end{array}$ \\
\hline
\end{tabular}

Source: Finklea \& Ribando (2017).

On the other hand, the militarization and US influence has stretched not only to Mexico's immigration policy but to other sectors of Mexico's political action as well. Over the last few years the US and the Mexican government have worked closely to fight against criminals and drug traffickers; some of the strategies, involving dangerous operations, have had highly unsuccessful fallouts. "These policies are part of the militarization of the entire society," 12 says Mr. Prado. For example, the Plan Merida established in 2008, not only allowed the US to send arms to the Mexican military and train the army to combat drug cartels, but also in- 
volved the improvement of border structures. After its restructuration in 2011, among the four pillars of the cooperation agreement were: 1) combating transnational criminal organizations by supporting Mexican intelligence with US technology and personnel, and 2) the creation of a $21^{\text {st }}$ century US-Mexican border while also improving security in the Mexico southern border. The Table 1 shows the Mérida funding for Mexico by Aid Account.

\subsection{Humanitarian local organizations as creators of new opportunities for migrants}

These organizations have been trying to offer to immigrants what other political bodies have not been able to, such as protection or just treatment. These organizations have the power to advocate a just immigration reform. The two associations located in San Diego, Border Angels and ASFC, work with different alliances at local, regional and national levels to promote human rights and just immigration policies. By fulfilling their moral responsibility, they are not only facilitating the continuance of human life, but also calling for a questioning of the morality and humanity of border policies.

On the Mexican side of the border the dynamic of migration has also changed significantly in the last years, since deportations, to Mexico and from Mexico, have increased considerably. According to Rev. Murphy, the processes and practices undertaken in the Casa del Migrante had to be adapted to this situation during the last years. "On average, from 100 immigrants that arrive to the house, 90 of them are deported," $"$ he says. As a consequence, in addition to the previous services they have been offering, such as food, shelter and counselling, they also have implemented new programs aimed to reintegrate migrants into the Mexican workforce. By giving them the opportunity to have a new start, they are promoting a new perspective of how they should be seen by the society; mainly as talented persons who also have the right to work in their home country. According to Rev. Murphy, deported migrants have a lot to offer, for example the majority of them are bilingual; however, a lot of them are also recruited by organized crime.

The Casa del Migrante projects open new paths for immigrants, even if it is after they have been sent back to their home country, showing that these organizations keep perceiving them as human beings that are in need. Since the beginning of their journey they have to face abuses and suffer from criminalization, as well as racial discrimination when living in the United States. When they are deported to their home countries, they still have to face difficulties as well as most of them might not know their rights as Mexican citizens.

Although these are relevant challenges, the faith-based organizations have fulfilled a meaningful role in the lives of immigrants. These organizations are mainly local, and their practices are less publicized; however, they have significantly helped to re-conceptualize the immigration experience by fulfilling what they consider to be their inherent moral responsibility. By offering immigrants a range of services, they counter the US government systematic approach and alleviate the situation that the government's policies have created along the border. 


\section{Conclusion}

In this paper, it was argued that high-level technologies implemented by the United States as part of their border enforcement strategy contributed to dehumanize migrants by reducing them to mere targets that must be detained. The development of US border strategies throughout the years has evolved to be the source of thousands of immigrant deaths, raising a moral concern that has been broadly addressed by numerous scholars and human rights organizations.

As was shown throughout the analysis, the implementation of military technologies has been the result of perceiving migrants as dangerous threats. The Border Patrol actions of militarization and increased surveillance are acts of sovereignty that are falsely supporting the idea of immigrants as criminal and terrorist threats. Although building walls and securing them with military instruments conveys a large territorial project, it carries a symbolic value as well. These actions are mere material symbol of states' desire to maintain their sovereignty intact. The US government argues that these practices are an important step to secure their borders against "terrorist threats"; however, these are more important to secure a positive international and public opinion on how capable they are of controlling their territory. As their ability to regulate their lands had been questioned, the US and other Western governments have become increasingly defensive and aggressive about their borders. The bodies of migrants are constantly stigmatized and targeted by exclusionary policies as they are criminalized agents (Silvey, 2005). This research demonstrates that the Border Patrol acts of militarization falsely portray immigrants as threats which is part of their securitization ideology born in the 1990s and intensified after the $9 / 11$.

On the other hand, by countering this position, the three faith-based organizations interviewed are only a representative sample of how immigrants can also experience moments of justice and humanity along their journey. Three main issues were found from the interviews conducted. The first was that the moral responsibility of the organizations allows them to exceed reductions, such as race or religious affiliation, considering every human being to be as equally important. The second issue is that the three organizations see the use of high-level technologies as a source of migrant abuses and deaths. Border Angels and AFSC fight actively to achieve a demilitarization of the border by advocating the annulment of policies and practices that have an impact on immigrants' lives and border communities as well. The third issue is related to the power that these organizations have to change both: the discourses of the US law enforcement agencies and the immigrant experience.

Nonetheless, it is important to consider that their role as creators of new opportunities comes with particular challenges that are profoundly related to the border enforcement; however, not exclusively caused by this situation. As social actors, faith-based organizations are immersed on the local dynamics of where they are situated. Aspects such as political support, access to resources, public opinion on migrants, funding/donations, and relationships with other organizations will also determine the level of success in offering assistance to those who arrive to their doors. For example, the level of acceptance of immigrants in Tijuana or San Diego will define how these organization will be able to help immigrant to immerse in their new community. Moreover, with the changing dynamics of the border immi- 
grants are in need of other types of support that civil organizations have to fulfill. In the case of Mexico, the role of these organizations is also changing as there are more deportees and people asking for asylum, who need assistance to integrate to a society in which, they feel, they do not belong.

\section{References}

Ahn, I.; Chiu, A. \& O'Neil, W. (2013) “And you welcomed me?: A theological response to the militarization of the US-Mexico borders and the criminalization of undocumented migrants." Association for Religion and Intellectual Life, Vol. 63, No. 3, 303-322.

Alvesson, M. \& Karreman, D. (2000) "Varieties of discourse: On the study of organizations through discourse analysis." Human relations, Vol. 53, No. 9, 1125-1149.

Amilhat, A. \& Giraut, F. (eds.) (2015) Borderities and the politics of contemporary mobile borders. New York: Palgrave Macmillan.

Amoore, L. (2006) "Biometric borders: Governing mobilities in the war on terror." Political geography, Vol. 25, No. 3, 336-351.

Angelucci, M. (2012) "US Border enforcement and the net flow of Illegal migration." Economic Development and Cultural Change, Vol. 60, No. 2, 311-357.

Anderson, J. (2003) "The US-Mexico border: A Half-century of change." The Social Science Journal, Vol. 40, No. 3, 535-554.

Argueta, L. (2016) Border Security: Immigration Enforcement Between Ports of Entry. Washington, D.C: Congressional Research Service.

Barry, T. (2010) Fallacies of High-Tech Fixes for Border Security. Washington, D.C.: Centre for International Policy.

Bigo, D. (2007) "Mobility controls and new technologies". In J. Lodge (ed.) Are you who you say you are? The EU and the biometrics of borders. Tilburg: Wolf Legal Publisher, 9-14.

Boggs, C. (2015) Mexico's Southern Border Plan: More Deportations and Widespread Human Rights Violations. Washington Office on Latin America. [Online. URL: $<$ https://www.wola.org/analysis/mexicos-southern-border-plan-more-deportations-andwidespread-human-rights-violations/>.Accessed on 4 July 2017].

Bosworth, M. (2008) "Border control and the limits of the sovereign state." Social \& Legal Studies, Vol. 17, No. 2, 199-215.

Brigden, N. K. (2018) "A visible geography of invisible journeys: Central American migration and the politics of survival." International Journal of Migration and Border Studies, Vol.4, No. 1-2, 71-88.

Brown, W. (2017) Walled states, waning sovereignty. Massachusetts: MIT Press.

Carter, N.; Bryant-Lukosius, D.; DiCenso, A.; Blythe, J. \& Neville, A. J. (2014) "The use of triangulation in qualitative research." Oncology nursing forum, Vol. 41, No. 5, 545547.

Cheek, J. (2004) "At the margins? Discourse analysis and qualitative research." Qualitative Health Research, Vol. 14, No. 8, 1140-1150.

Customs and Border Protection (2017) US Border Patrol Fiscal Year Budget Statistics (FY1990-FY2015). [Online. URL: <http://www.cbp.gov/newsroom/mediaresources/stats?title=Border+Patrol $>$. Accessed 16 September 2017].

Customs and Border Protection (2018) US Border Patrol fiscal Year staffing statistics (FY1992-FY 2017). [Online. URL: <http://www.cbp.gov/newsroom/mediaresources/stats?title=Border+Patrol $>$. Accessed 17 September 2018]. 
Corporate Watch (2015) Elbit Systems. [Online. URL: $<$ https://corporatewatch.org/company-profiles/elbit>. Accessed 12 August 2017].

Crepeau, F., Nakache, D. \& Atak, I. (2007) "International Migration: security Concerns and human rights standards." Transcultural Psychiatry, Vol. 44, No. 3, 311-337.

Department of Homeland Security (n.d.) Technology investments between Ports of Entry. [Online. URL: <https://www.dhs.gov/taxonomy/term/3556/all/feed $>$. Accessed on 20 October 2019].

Doty, R. (2006) "Fronteras Compasivas and the Ethics of Unconditional Hospitality." Journal of International Studies, Vol. 35, No. 1, 53-74.

Doty, R. (2011) "Bare life: border-crossing deaths and spaces of moral alibi." Environment and Planning D: Society and Space, Vol. 29, No. 4, 599-612.

Ewing, W. (2010) Looking for a Quick Fix: The rise and fall of the secure border initiative's high-tech solution to unauthorized migration. Washington, DC: IPC United States Government.

Finklea, K. \& Ribando, C. (2017) US-Mexican Security Cooperation: The Mérida Intitaive and Beyond. [Online. Retrieved from Congressional Research Centre website. URL: $<$ https://fas.org/sgp/crs/row/R41349.pdf $>$. Accessed on 15 September 2018].

Graham, M. (2013). Issue Brief: Border Security Assets. Bipartisian Policy Center [Online. URL: $<$ http://issuu.com/bipartisanpolicycenter/docs/border_assets $>$. Accessed on $10 \mathrm{Ju}-$ ly 2017].

Hayes, A. \& Mason, R. (2013) "Securing twenty-first century societies.” In S. Nikalus, R. Mason and A. Haye (eds.) Migration and Insecurity: citizenship and social inclusion in a transnational era. New York: Routledge, 3-16.

Hagan, J. (2008) Migration Miracle: Faith, Hope and Meaning of Undocumented Journey. Massachusetts: Harvard University Press.

Hondagneu-Sotelo, P.; Gaudinez, G.; Lara, H. \& Ortiz, B. C. (2004) "There's a spirit that transcend the border": Faith, ritual, and postnational protest at the US-Mexico border." Sociological Perspectives, Vol. 47, No. 2, 133-159.

Iacson, A.; Meyer, M. \& Morales G. (2014) Mexico's other border: security, migration and the humanitarian crisis at the line with Central America. Washington Office on Latin America [Online. URL: <http://www.wola.org/files/mxgt/report/>. Accessed on 1 December 2017].

Johnson, C.; Jones, R.; Paasi, A.; Amoore, L.; Mountz, A.; Salter, M. \& Rumford, C. (2011) "Interventions on rethinking «the border» in border studies." Political Geography, Vol. 30, No. 2, 61-69.

Jones, R. (2016) Violent borders: Refugees and the right to move. New York: Verso Books.

Klein, E. (2013) "Everything you know about immigration is wrong." The Washington Post, August $10^{\text {th }} 2013 . \quad$ [Online. URL: $<$ https://www.washingtonpost.com/news/wonk/wp/2013/08/10/everything-you-knowabout-immigration-is-wrong/ $>$. Accessed on 9 October 2017].

Massey, D. \& Sánchez, M. (2010) Brokered Boundaries: Creating Immigrant Identity in Anti-Immigrant Times. New York: Russell Sage Foundation.

McCune, B. \& Soden, D. (2009) "Regulating the Push and Pull of migration in the post 9/11 era on the southern border." In M. Morgan (ed.) The Impact of 9/11 and the new legal landscape: the day that changed everything? London: Palgrave Mcmillian, 189204

Meissner, D. \& Pierce, S. (2019). Policy Solutions to Address Crisis at Border Exist, But Require Will and Staying Power to Execute. Migration Policy Institute. [Online. URL: 
$<$ https://www.migrationpolicy.org/news/policy-solutions-address-crisis-border-existrequire-will-staying-power $>$. Accessed on 9 May 2019].

Miller, T. (2013) "Surveillance Surge on the Border: How to Turn the US- Mexican Border into a War Zone." Truthout, July 11th. [Online. URL: <http://www.truthout.org/news/item/17513-surveillance-surge-on-the-border-how-to-turn-the-usmexican-border-into-a-war-zone>. Accessed on 23 October 2017].

Morrisey, K. (2018) "«Door of Hope» is closed to cross-border hugs and weddings." Los Angeles Times, January $6^{\text {th }} 2018 . \quad$ [Online. URL: $<$ https://www.latimes.com/local/lanow/la-me-ln-sd-door-of-hope-20180106story.html>. Accessed on 30 October 2018].

Mountz, A. (2011) "Specters at the Port of Entry: Understanding State Mobilities through an Ontology of Exclusion." Mobilities, Vol. 6, No. 3, 317-34.

Office of Inspector General (2014) US Customs and Border Protection's Unmanned Aircraft System Program does not achieved intended results or recognize all costs of operations. [Online. URL: <https://www.oig.dhs.gov/.../OIG_15-17_Dec14.pdf>. Accessed on 13 October 2017].

Orraca, P. (2014) "Immigrants and Cross-border workers in the US-Mexico border region." Frontera norte, vol. 27, núm. 53, 5-34.

Paasi, A. (2009) "Bounded spaces in a borderless world: border studies, power and the anatomy of territory." Journal of Power, Vol. 2, No. 2, 213-134.

Pries, L. \& Pauls, R. (2013) "Introduction: New Dynamics of Migration and Belonging." In L. Pries (ed.) Shifting boundaries of belonging and new migration dynamics in Europe and China. Hampshire, England: Springer, 1-18.

Pope, J. \& Garret, T. (2013) “America's Homo Sacer: Examining US Deportation Heraings and the criminalization of illegal immigration." Administration and Society, Vol. 45, No. 2, 167-186.

Ramirez, C. (2011) “The Open wound of the US-Mexico border.” In Rights Working Group Report.Reclaiming our rights: Reflections on racial profiling in a post 9/11 America. 35-37.

Sassen, S. (2014) Expulsions: Brutality and Complexity in the Global Economy. Cambridge, Massachusetts: Harvard University Press.

Salter, M. (2013) "Introduction." In M. Salter and C. Mutlu (eds.) Research Methods in Critical Security Studies. An Introduction. New York: Routledge, 1-15.

Silvey, R. (2005) "Borders, embodiment, and mobility: Feminist migration studies in geography." In L. Nelson and J. Seager (eds.) A companion to feminist geography. Malden: Blackwell, 138-149.

Stuckey, H. L. (2013) "Three types of interviews: Qualitative research methods in social health." Journal of Social Health and Diabetes, Vol. 1, No. 2, 56-59.

US Customs and Border Protection (2004) National Border Patrol Strategy. [Online. URL: $<$ https://www.hsdl.org/?view\&did=457100 $>$. Accessed on 23 August 2017].

US Customs and Border Protection (2012) 2012-2016 Border Patrol Strategic Plan. [Online. Retrieved from the CBP website. URL: <http://www.cbp.gov/bordersecurity/along-us-borders/strategic-plan>. Accessed on 26 August 2017].

US Customs and Border Protection (2015) Vision and Strategy 2020. [Online. URL: $<$ http://www.cbp.gov/document/publications/vision-and-strategy-2020>. Accessed on 7 August 2017].

US Customs and Border Protection (2018) Border Patrol History. [Online. URL: $<$ https://www.cbp.gov/border-security/along-us-borders/history>. Accessed on 12 May 2019]. 
US Customs and Border Protection (2019a) San Diego Sector California. [Online. URL: $<$ https://www.cbp.gov/border-security/along-us-borders/border-patrol-sectors/sandiego-sector-california $>$. Accessed on 21 October 2019].

US Customs and Border Protection (2019b) About CBP. [Online. URL: $<$ https://www.cbp.gov/about $>$. Accessed on 21 October 2019].

United States Environmental Protection Agency (2016) Border 2020: US-Mexico Environmental Program: State of the Border Region Indications Interim Report. [Online. URL: $<$ https://www.epa.gov/sites/production/files/2017-

01/documents/state_of_the_border_region_2016_122216.pdf $>$. Accessed on 19 May 2019].

Villareal, A. (2019) US Mexico economic relations: trends, issues and implications. Congressional Research Service. RL32934.

Waller, D. (2005) US Border Enforcement from horseback to high-tech. Migration Policy Institute [Online. URL: <http://www.migrationpolicy.org/article/horseback-high-techus-border-enforcement>. Accessed on 22 September 2017].

Walters, W. (2004) "Secure borders, safe heaven, domopolitics." Citizenship Studies, Vol. 8, No. 3, 237-260.

Walters, W. (2006) "Rethinking borders beyond the state." Comparative European Politics, Vol. 4, No. 1, 141-159.

Wilson, V. (2012) "Research methods: interviews." Evidence Based Library and Information Practice, Vol. 7, No. 2, 96-98. 